\title{
Technology and Organization of Accounting: Recent Changes
}

\author{
Zoya Ivanovna Latysheva, Elena Viktorovna Skripkina, Olga Ilinichna Mamrukova, Ekaterina \\ Yevgenievna Listopad, Vera Vitalievna Zholudeva
}

\begin{abstract}
The article is concerned with the substantiation of approaches to the rational organization of accounting in modern conditions. It is established that the institutional basis for the development of socio-economic phenomena logically sets the problem of the need to reform accounting as a technological aspect, where some changes will occur in the operational information system. It is proved that the institutional model of accounting should be aimed at a significant increase in the efficiency of mechanisms for implementing rules and bridging institutional gaps. It is revealed that current trends in the development of society and business, the existing challenges and risks that have arisen as a result of ill-conceived management at all levels of management require the urgent development of a concept for the further development of accounting, which should significantly simplify it based on the European principles of standardization and harmonization of accounting.
\end{abstract}

Keywords: organization, accounting, business, concept, management, politics, economics, space.

\section{INTRODUCTION}

The rational organization of accounting can be presented in the form of accounting policies of both the state and the business entity. Accounting policies at the state level should accommodate such factors as the level of market economy development, the degree of democratization of public relations, the expansion and deepening of integration of the country's economy into the global economic space, and the country's compliance with the requirements of international institutions for standardization and harmonization of accounting.At the same time, accounting should be carried out in order to create uniform rules for its maintenance, which are mandatory for all enterprises and guarantee the interests of the users. The organization of accounting is the object of scientific research, a critical analysis of the components of the regulatory legal acts of the state and the accounting policies of business entities of various forms of ownership and types of economic activity as politicians, scientists, professional accountants, supervisors, and analysts.An analysis of recent

Revised Manuscript Received on November 15, 2019

Zoya Ivanovna Latysheva, Federal State Budget Educational Establishment of Higher Education «Kursk State Agricultural I.I. Iyanov Academy», Kursk, Russia.

Elena Viktorovna Skripkina, Federal State Budget Educational Establishment of Higher Education «Kursk State Agricultural I.I. Iyanov Academy», Kursk, Russia.

Olga Ilinichna Mamrukova, Moscow International University, Moscow, Russia.

Ekaterina Yevgenievna Listopad, Financial University Under the Government of The Russian Federation, Moscow, Russia.

Vera Vitalievna Zholudeva, Federal State Budgetary Educational Institution of Higher Education «Yaroslavl State Agricultural Academy», Yaroslavl, Russia. research and publications makes it possible to argue that in the scientific and practical dimensions, the rational organization of accounting in modern conditions is a complex problem. This is proved by the research performed by Asfandiyarova [1], Belonogov [2], Korotkova [3], Kuzmin [4], Malitskaya [5], Sycheva [6], Arbidane, Mietule [7]; Budrionyte, Gaižauskas [8], 2018; Subačienè et al. [9] , Puryaev and Puryaev [10], Vegera et al. [11] and others.The research is mainly concerned with a systematic study of theoretical, methodological, organizational, and practical principles of accounting. However, there is a lack of a system narrative of the state and development of the accounting, control and analysis system as important management functions in the context of socio-political instability in the country and the destructive processes of the systemic crisis.

\section{PROPOSED METHODOLOGY}

The methodological basis for the preparation includes the general scientific methods of cognition of objective reality associated with the complex operational processes of the control system and its important functions in risky conditions, namely: the method of a systematic approach, analysis and synthesis, the method of determination, the inductive-deductive approach, as well as the historical method. The tabular method of research is used to illustrate the hierarchical levels of the rational organization of accounting and the stages of its methodology development.

The information base of the article is the statistical data of state bodies, legislative and regulatory documents regulating the processes of rational organization of accounting in modern conditions.In the research process, it is planned to improve the approaches to the organization of accounting, to develop the measures to coordinate the activities between the main participants in the accounting process, to justify the provision on the formation of a rational organization of accounting that ensures the development of business entities.

\section{RESULT ANALYSIS}

The accounting policies of business entities should pay due consideration to the following factors: the form of ownership; the organizational and legal structure of the enterprise; licensing and accreditation of the type of economic activity, which determines the features and conditions of the accounting work; the parameters of the enterprise in terms of assets, operating income, product range, number of employees; relations with the fiscal system, the availability of benefits and the conditions for their receipt; the conditions for the formation of resources and 
the sale of finished products.

At the same time, current legislation provides broad rights in relation to the formation and implementation of the accounting policies, subject to the necessary compliance with the basic principles of accounting (Figure 1).

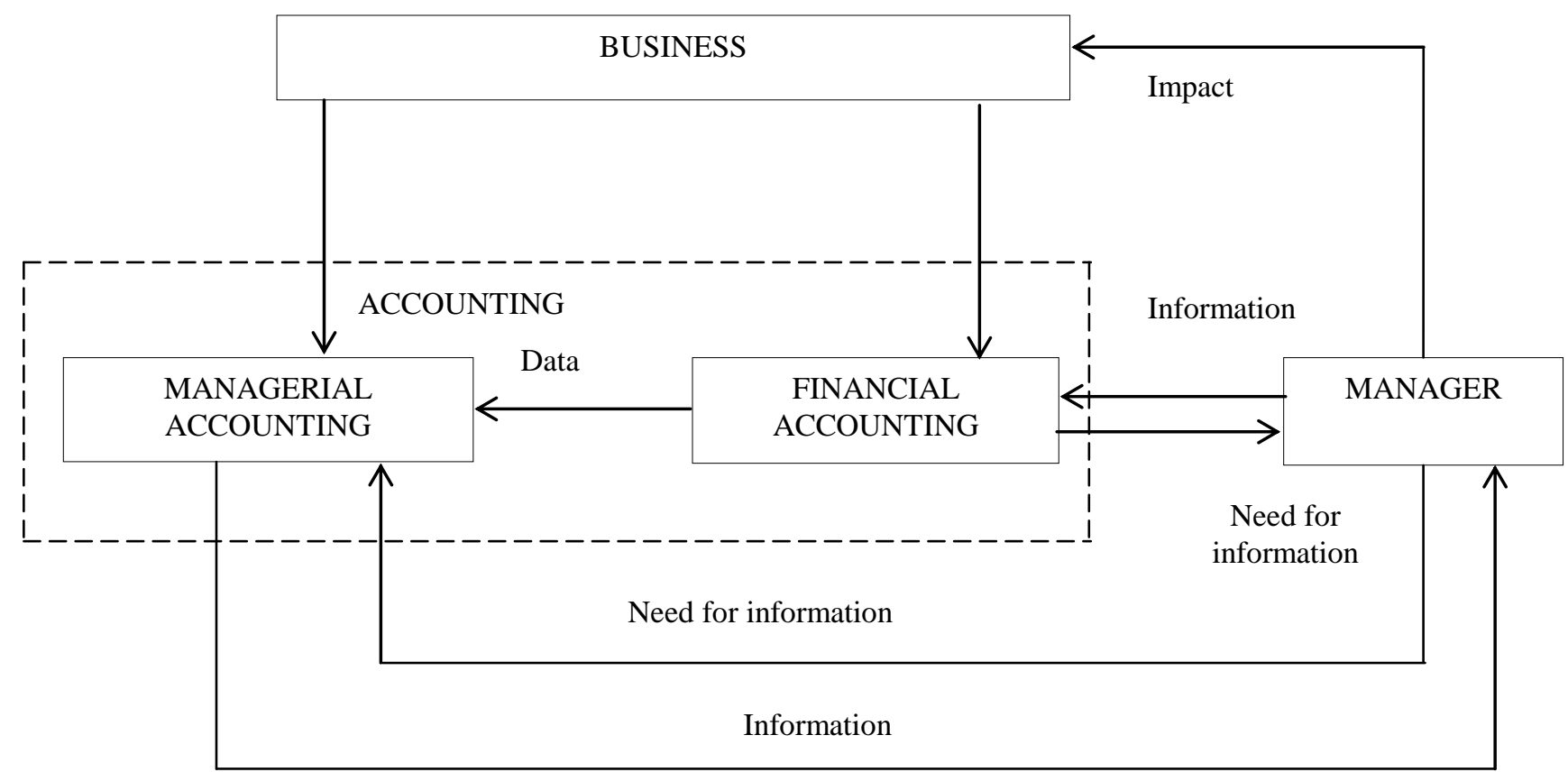

Fig. 1: Formation of a rational accounting system

Therefore, a change in accounting policy is possible in cases provided for by national accounting regulations, related to the changes in legislation, the development and application of new accounting methods, or significant changes in the operating conditions or structure of the enterprise.

However, the qualified development and adoption of an entrepreneurial policy are the key to the successful operation of the enterprise, avoidance of fiscal sanctions, the efficiency of decisions made and the activities of the enterprise. Since the accounting policy and the accounting and reporting regulation system are determined by the factors of the institutional environment with its conditions and decisions, these factors can be considered in the following sequence: strategies for reformation of the accounting and reporting system in compliance with international requirements, assessment of the harmonization and standardization of accounting, the degree of influence of accounting analytical science on the development and implementation of modern approaches to the process of reformation and regulation of accounting, control and audit, a critical analysis of the project changes in existing acts, modern views on the state of accounting in the face of uncertainty and systemic crisis.

Moreover, the reformation of the accounting and reporting system is performed in the context of harmonization and standardization of the needs of market economy development. Public joint-stock companies, banks, insurers, as well as the enterprises engaged in business activities by types, the list of which is determined by public authorities, are required to prepare financial statements in accordance with international standards. However, the enterprises can determine the appropriateness of the application of international standards to financial reporting. The only thing required is to inform the state statistics authorities in the prescribed manner about financial reporting in accordance with international standards.

Full and effective management of accounting and analytical information allows managers to make balanced and timely managerial decisions. Therefore, in a globalized world, international standards are not only a benefit but also an additional responsibility for the quality of financial information in particular. Keeping records according to international standards requires the restructuring of modern management, including managers of all levels, the involvement of highly qualified and highly paid accountants, significant retraining of personnel, software retrofit, improvement of the decision-making system, and mandatory ongoing audit support.

The discussion on the application of the international financial reporting standards for fiscal purposes does not cease; in particular, it is escalated during the discussion of draft amendments to tax legislation. Along with constructive remarks and suitable proposals, unjustified criticism is expressed with the sole purpose to discredit the changes or legislatively secure certain special interests.

Meanwhile, the authors of proposals, as a rule, transcend the limits of competence and often do not understand that the implementation of the doctrine on reformation of the economies cannot apply the models, the theoretical basis of which is formed in other realities, under different economic conditions, and with a different mental and social structure of society. Moreover, any borrowings and analogies should be carefully justified before they are recommended for implementation.

However, this postulate is unfortunately ignored by economists. It should be kept in mind that international financial reporting standards were developed for the needs of multinational companies. Therefore, they are based on methodological principles adopted for large enterprises, mainly of joint-stock form. The international financial reporting standards are necessarily applied only to the 
consolidated financial statements of companies, the securities of which are authorized for trading in the regulated market of any member state.

The ideology of international standards makes them unacceptable for fiscal purposes. Since the professional judgment of the accountant and auditor plays an important role in the recognition of costs and revenues, the importance of this role is due to the lack of specificity in the standards; they introduce a general direction and are designed for a conscious, rational and responsible executive.

It should not be forgotten that full-fledged accounting according to international standards requires the involvement of highly qualified and highly paid specialists, retraining of personnel, software changes, improvement of the decision-making system, and constant audit support. Therefore, the proposals of some scholars and practicing accountants on the application of international financial reporting standards with fiscal goals in the current conditions are unacceptable due to their unsuitability for an objective and impartial determination of the object of taxation and discrediting the very idea of introducing international standards. Therefore, the strategy adopted by the Russian Federation for application of international financial reporting standards involves a differentiated approach to their use for organizations in the state sector (Table 1).

Table 1: Federal Accounting Standards for Public Sector Organizations

\begin{tabular}{|l|c|c|}
\hline $\begin{array}{l}\text { Federal accounting standards } \\
\text { for public sector organizations }\end{array}$ & Date of adoption and number of the order & Effective date \\
\hline $\begin{array}{l}\text { Conceptual Fundamentals of } \\
\text { Accounting }\end{array}$ & $\begin{array}{c}\text { Order of the Ministry of Finance of Russia dated December 31, 2016 No. } \\
256 \mathrm{n} \text { (reg. No. 46517) }\end{array}$ & January 1, 2018 \\
\hline Fixed assets & $\begin{array}{c}\text { Order of the Ministry of Finance of Russia dated December 31, 2016 No. } \\
\text { 257 (reg. No. 46518) }\end{array}$ & January 1, 2018 \\
\hline Rent & Order of the Ministry of Finance of Russia dated December 31, 2016 No. & January 1, 2018 \\
\hline $\begin{array}{l}\text { Depreciation of assets } \\
\text { Presentation of financial } \\
\text { statements }\end{array}$ & $\begin{array}{c}\text { Order of the Ministry of Finance of Russia dated December 31, 2016 No. } \\
259 \mathrm{n} \text { (reg. No. 46520) }\end{array}$ & January 1, 2018 \\
\hline
\end{tabular}

At the same time, financial reporting of large enterprises that attract capital has to comply with international standards, while small enterprises can apply simplified national standards. In no small measure, this is due to the need not only to simplify but also to reduce the cost of accounting by small and medium-sized enterprises.

Undoubtedly, an important role in the creation of a modern accounting regulation system is played by accounting science, which is concentrated mainly in national universities. Recently, it was proposed to transfer the functions of accounting development management to public organizations instead of government bodies. All this, without a doubt, reduces the degree of responsibility, the possibility of control and, as a result, can become the path to serious abuse.

As for the training of professional accountants, the declared change introduces the mandatory training and certification of all practicing accountants through a system of public and nongovernmental structures. This is a way to further undermine the financial condition of domestic enterprises that are not able to pay for the certification of their accountants, the cost of which per unit of academic load currently exceeds the cost of studying at higher education institutions on a commercial basis.

At the same time, the process of organization of accounting occurs during permanent changes to a number of codes, laws, standards, and regulations governing accounting and reporting. All business entities, depending on their legal status, forms of ownership, size of production, number of employees, and other parameters have their own accounting models. An accounting model should be understood as a normally regulated restoration of the accounting system that

\section{DISCUSSION}

The reliability of the presented approaches is confirmed by explains the subject, object, methods, and procedures of accounting and reporting by a business entity.

In this aspect, the accounting model for microenterprises, the accounting model for small enterprises, the accounting model for medium-sized enterprises, and the accounting model for large enterprises are distinguished by the authors. The proposals to establish criteria for the classification of enterprises as microenterprises, small enterprises, medium-sized enterprises, and large enterprises are very important in terms of statutory regulation of enterprises. For example, the authors refer to microenterprises the business entities whose indicators as of the date of financial reporting for the previous year meet only a few criteria: the total value of assets is 350 thousand euros; the net income from sales of products (goods, works, services) is up to 700 thousand euros; the average annual number of employees is up to 10 people.

Small enterprises are those that do not meet the criteria for microenterprises and have a total asset value of up to 4 million euros; the net income from sales of products (goods, works, services) - up to 8 million euros; the average annual number of employees in which is up to 50 people. Medium-sized enterprises are those that do not meet the criteria for small enterprises and have a total asset value of up to 20 million euros; net income from sales of products (goods, works, services) - up to 40 million euros; the average annual number of employees is up to 250 people. Large enterprises are those, whose indicators exceed the criteria established for international enterprises, and the total value of assets is more than 20 million euros; the net income from sales of products (goods, works, services) is more than 40 million euros; the average annual number of employees is more than 250 people the fact that a fundamentally new objective is to develop accounting models for the 
enterprises of public interest, taking into consideration their monopolistic market position and legislatively secured confidentiality of the accounting and analytical information on income and expenses related to their activities. All this is unacceptable in the formation of tariffs, prices, and other conditions. Legislatively, it is necessary to strengthen the requirements for such enterprises that are of public interest, for their chief accountants or for persons providing accounting and reporting.

At the same time, the collaborative effort of scientists, practitioners of bookkeeping companies, employers and senior officials of the ministries and departments would be productive through holding joint conferences, aimed at the presentation of the results of fundamental research on the most important problems of accounting, analysis, control, audit, and reporting in modern conditions of globalization processes in the world economy, as well as their discussion and exchange of experience, development of scientific recommendations for business entities and state authorities in order to facilitate their practical implementation.

A critical analysis of the accounting development problems proves the urgent need for the use of institutional analysis as an interdisciplinary method in accounting research to study its properties and identify development trends. Provision of the accounting information formation with the mandatory observance of the established rules and order is achieved through institutionalization.

The factors of formation of the institutional accounting model, which determines the structure and the institutional segmentation of the accounting institution and its relationship with other institutions in the formation and use of the economic information, require an in-depth study and system analysis. The above segments of institutional influence ignore the socio-economic institution of accounting, which must be considered as a system of normative rules (formal) and legislatively unspecified ones (informal), but able to affect the accounting policies and practices, as well as the mechanisms for ensuring the compliance with these rules.

\section{CONCLUSION}

Summing up, it can be noted that the institutional framework for the development of socio-economic phenomena logically sets the problem of the need to reform accounting as a technological aspect, where the changes will occur in a functioning information system. Therefore, the institutional model of accounting should be aimed at a significant increase in the efficiency of the mechanisms for implementation of the rules and bridging the institutional gaps that are closely related to the subjective effect on the deformation of the information volumes.

Moreover, the declared European development vector, which includes the participation in the international distribution and cooperation of labor, attraction of foreign investment in the economy, and the entry of domestic enterprises into the international markets for goods, capital and labor, requires a real reformation in the field of formation of the state accounting policy,solution of the most important problems of accounting system regulation, and the introduction of an open and transparent methodology for the disclosure of economic information by business entities of all forms of ownership.

At the same time, current trends in the society and business development, the existing challenges and risks arising from poorly thought-out business management at all levels of management require urgent development of a concept for the further development of accounting, which should significantly simplify it on the basis of pan-European principles of standardization and harmonization of accounting and reporting, eliminate their dependence on the negative impact of business groups.

\section{REFERENCES}

1. R.A. Asfandiyarova, G.I. Gabbasova,"Uchet inventarizatsi imushchestva organizatsii" [Organizational Property Inventory Accounting], Alleya nauki, 2(3(30)), 2019, pp. 297-303.

2. V.D. Belonogov, "Innovatsionnye protsessy bukhgalterskogo ucheta $i$ nalogooblozheniya $\mathrm{v}$ mikrofinansovykh organizatsiyakh" [Innovative Processes of Accounting and Taxation in Microfinance Organizations], Birzha intellektualnoi sobstvennosti, 14(10), 2015, pp. 37-39.

3. O.V. Korotkova, Zh.A. Tislenko, "Organizatsiya bukhgalterskogo ucheta dlya analiza likvidnosti organizatsii" [Organization of Accounting for the Analysis of the Liquidity of the Organization], APRIORI. Ceriya: Gumanitarnye nauki, 3, 2016, p. 21.

4. O.V. Kuzmin, V.A. Melnikova, "Vychislenie parametrov protsessa planirovaniya zapasov topliva TETs na osnove matrits iz odnorodnykh polinomov Bella" [Calculation of the Parameters of the Process of Planning the Fuel Reserves of Thermal Power Plants Based on Matrices of Homogeneous Bell Polynomials]. Sovremennye tekhnologii. Sistemnyi analiz. Modelirovanie, 4(40), 2013, pp. 8-14.

5. V.B. Malitskaya, M.B. Chirkova, I.V. Kuznetsova, "Sovershenstvovanie rossiiskogo ucheta sobytii posle otchetnoi daty v sootvetstvii s MSFO" [Improvement of the Russian Accounting of the Events after the Reporting Date in Accordance with IFRS], Vestnik Voronezhskogo gosudarstvennogo agrarnogo universiteta, 3(58), 2018, pp.190-196.

6. I.V. Sycheva, "Sovremennye tendentsii razvitiya publichnogo upravleniya v Rossii" [Modern Trends in the Development of Public Administration in Russia], Izvestiya Tulskogo gosudarstvennogo universiteta. Ekonomicheskie i yuridicheskie nauki, 3-1, 2012, pp.3-12.

7. Arbidane, I. Mietule, "Problems and solutions of accounting and evaluation of biological assets in Latvia", Entrepreneurship and Sustainability Issues, 6(1), 2018, pp. 10-22. http://doi.org/10.9770/jesi.2018.6.1(1)

8. R. Budrionytė, L. Gaižauskas, "Historical cost vs fair value in forest accounting: the case of Lithuania", Entrepreneurship and Sustainability Issues, 6(1), 2018, pp. 60-76. http://doi.org/10.9770/jesi.2018.6.1(5)

9. R. Subačienė, L. Alver, I. Brūna, M. Hladika, D. Mokošová, J. Molín, "Evaluation of accounting regulation evolution in selected countries", Entrepreneurship and Sustainability Issues, 6(1), 2018, pp. 139-175. http://doi.org/10.9770/jesi.2018.6.1(11)

10. A. Puryaev, A.A. Puryaev, "Mathematical tooling of accounting non-economic characteristics during the assessing process of investment project effectiveness", Entrepreneurship and Sustainability Issues, 7(2), 2019, pp. 1114-1135. http://doi.org/10.9770/jesi.2019.7.2(23)

11. S. Vegera, A. Malei, I. Sapeha, V. Sushko, "Information support of the circular economy: the objects of accounting at recycling technological cycle stages of industrial waste", Entrepreneurship and Sustainability $\begin{array}{llll}\text { Issues, } & 6(1), & 2018, & \text { pp. }\end{array}$ http://doi.org/10.9770/jesi.2018.6.1(13) 